\title{
The urinary excretion of aromatic acids by starved sheep
}

\author{
BY A. K. MARTIN \\ Hannah Dairy Research Institute, Ayr \\ (Received 3 February 1969-Accepted 2 March I969)
}

\begin{abstract}
r. Four wether sheep were maintained on a diet of hay for 2 weeks and then starved for a period of 4 days.

2. Immediately before and during starvation the urinary excretion in the following fractions was determined: hippuric acid, creatinine, total diethyl ether-soluble acids of hydrolysed and unhydrolysed urine, total aromatic acids in hydrolysed and unhydrolysed urine and the proportion of the former present as benzoic and phenylacetic acids.

3. A method for determining the benzoic acid content of light petroleum extracts of urine has been developed and is described.

4. Starvation had little effect on the urinary excretion of phenylacetic acid or creatinine, but during the first 2 days of starvation there were large decreases in the excretion of all the other urinary fractions studied.

5. Of the fractions examined, $43 \%$ of the diethyl ether-soluble acids of hydrolysed urine and $42 \%$ of those of unhydrolysed urine were of exogenous origin; $76 \%$ of the total urinary aromatic acids were of exogenous origin. Partition of the aromatic acids in the urine of two of the four sheep indicated that the reduction in aromatic acid excretion on starvation was completely accounted for by the decline in benzoic acid output. Almost all the hippuric acid ( $97 \%$ ) was of exogenous origin.

6. These results have been compared with the urinary output of aromatic acids by nonruminants when fasted, and possible reasons for the relatively large amounts of phenylacetic acid found in the urine of starved sheep have been discussed.
\end{abstract}

Several investigations of the endogenous aromatic acid production of non-ruminants have been made. Stein, Paladini, Hirs \& Moore (1954) reported that the aromatic moieties of hippuric acid and phenylacetylglutamine excreted in the urine of man are almost entirely of endogenous origin. Isotope dilution experiments (Schreier, Altman \& Hempelmann, 1954) have demonstrated the endogenous production of small amounts of benzoic acid in fasted rats. Phenylalanine has been shown by several workers (e.g. Bernard, Vuilleumier \& Brubacher, 1955; Armstrong, Chao, Parker $\&$ Wall, 1955) to be a precursor of small amounts of endogenously produced benzoic acid.

Ruminants excrete considerably greater quantities of aromatic acids in their urine than do non-ruminants (Martin, 1969). Although this is probably largely a consequence of metabolism in the digestive tract and body tissues of exogenous precursors, endogenous metabolism may account for a proportion of these acids. There is no published information on the endogenous output of aromatic acids by ruminants.

The object of the experiments described in this paper was to study the effect of fasting on the urinary excretion of aromatic acids by sheep. These experiments have shown that while the urinary benzoic acid excretion of sheep rapidly fell to very low levels on withholding food for periods of 3 or 4 days, phenylacetic acid excretion remained the same as that found when a hay diet was fed. 


\section{EXPERIMENTAL}

\section{Animals and plan of experiments}

Four wether sheep were used; one was an 8-year-old Down Cross (no. I), two were 3-year-old Hampshires (nos. 2 and 3 ) and one was a 3 -year-old Kent (no. 4).

The sheep were maintained during the period of the experiments in metabolism cages in a room in which the temperature varied between $15^{\circ}$ and $20^{\circ}$. They were given a diet of $600 \mathrm{~g}$ poor-quality hay daily for a period of 2 weeks. Food was then withheld for a period of 4 days, but during that time water was available ad lib. Urine was collected quantitatively on the last day of feeding and also on the subsequent 4 days of starvation. The collection vessels contained a mixture of potassium dichromate and mercuric chloride as preservative and the apparatus previously described was used (Martin, I966). The daily excretion of urine obtained from each sheep was weighed and portions were taken for the analyses described below. All analyses were begun on the day of sampling.

The weights of the sheep on the last day of giving the hay diet and on the $4^{\text {th }}$ day of starvation were respectively: sheep no. $1,5^{8.6}$ and $56.3 \mathrm{~kg}$; sheep no. $2,66 . \mathrm{I}$ and $64 \cdot 8 \mathrm{~kg}$; sheep no. $3,6 \mathrm{r} \cdot 4$ and $58 \cdot 8 \mathrm{~kg}$; sheep no $4,65 \cdot 9$ and $6 \mathrm{r} \cdot 6 \mathrm{~kg}$.

The last day of feeding is referred to as day $I$ of the experiment and the 4 subsequent days of starvation as days $2-5$.

\section{Analytical methods}

All analyses of urinary acids are expressed in terms of acidity equivalent to benzoic acid (BAE).

Hydrolysis of conjugated acids in urine. To I volume of urine 0.125 volumes of Io $\mathrm{N}-\mathrm{KOH}$ were added and the sample was heated in a sealed tube at $95^{\circ}$ for $\mathrm{I} 6 \mathrm{~h}$.

Total aromatic acids in urine. The titratable acidities of diethyl ether and light petroleum (boiling range $40-60^{\circ}$ ) extracts of acidified urine were determined before and after hydrolysis as described previously (Martin, 1969). The diethyl ether extracts have been shown to contain aliphatic, phenolic, indolyl and aromatic acids, and their conjugates, but the light petroleum extracts contain only aromatic acids (Martin, 1969).

Benzoic acid in light pertoleum extracts of hydrolysed urine. This analysis was carried out on the urine of two of the four experimental sheep (nos. 2 and 4). Use was made of the large absorption peak at $225 \mathrm{~nm}$ shown by benzoic acid in $0.01 \mathrm{~N}-\mathrm{NaOH}$ (Kumler \& Strait, 1943). Light is not absorbed at this wave length by 3-phenylpropionic acid and phenylacetic acid shows only a slight absorption. The ultraviolet absorption spectra of these acids are shown in Fig. I.

After continuous extraction of the urine with light petroleum as already described, the extract was adjusted to a volume of $100 \mathrm{ml}$. The titratable acidity of a portion of this extract was determined. Another portion of this extract, calculated to contain ro- $25 \mathrm{mg}$ benzoic acid (assuming $70 \%$ of the acidity to be due to benzoic acid) was then extracted three times with $25 \mathrm{ml}$ of $0.25 \mathrm{~N}-\mathrm{NaOH}$. The alkaline extracts were combined and made to $100 \mathrm{ml}$ with $0.25 \mathrm{~N}-\mathrm{NaOH}$ and a portion of this solution was diluted with water to give a solution of aromatic acids in $0.0 \mathrm{r}-\mathrm{NaOH}$. A blank 
extract was prepared by extracting the appropriate volume of light petroleum with $0.25 \mathrm{~N}-\mathrm{NaOH}$. The blank extract was used as the reference solution in scanning the absorption from $300 \mathrm{~nm}$ to $205 \mathrm{~nm}$ in an $\mathrm{SP}_{5} 00$ spectrophotometer (Unicam Instruments Ltd, Cambridge, England).

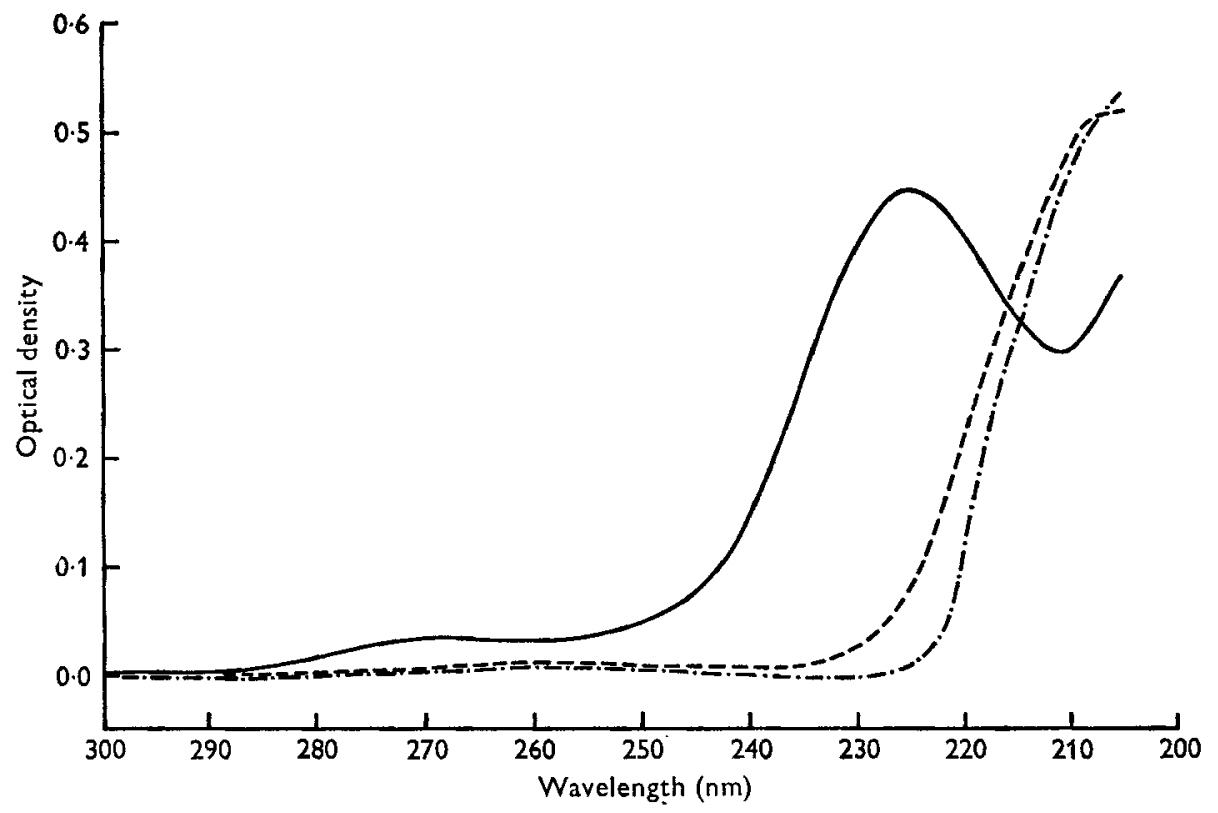

Fig. I. Ultraviolet absorption spectra of benzoic, phenylacetic and 3-phenylpropionic acids in $0 \cdot 0 \mathrm{~N}-\mathrm{NaOH}$. —, benzoic acid $6.45 \mu \mathrm{g} / \mathrm{ml} ;---$, phenylacetic acid $7 \cdot 70 \mu \mathrm{g} / \mathrm{ml} ;-\cdots-\cdot$, 3 -phenylpropionic acid $6.88 \mu \mathrm{g} / \mathrm{ml}$.

Table $\mathrm{I}$. The molecular extinction $\left(6 \times \mathrm{IO}^{-3}\right)$ of benzoic, phenylacetic and 3-phenylpropionic acids extracted from light petroleum into $0 \cdot 0 \mathrm{O} \mathrm{N}-\mathrm{NaOH}$

$\begin{array}{cccc}\begin{array}{c}\text { Wavelength } \\ \text { (nm) }\end{array} & \begin{array}{c}\text { Benzoic } \\ \text { acid }\end{array} & \begin{array}{c}\text { Phenylacetic } \\ \text { acid }\end{array} & \begin{array}{c}\text { 3-Phenylpropionic } \\ \text { acid }\end{array} \\ 270 & 0.63 & 0.08 & 0.05 \\ 235 & 5.09 & 0.10 & 0.00 \\ 225 & 8.35 & 1.35 & 0.05 \\ \text { 21 } & 5.61 & 7.15 & 7.63\end{array}$

The optical density at $235 \mathrm{~nm}$ is almost entirely due to benzoic acid. At $225 \mathrm{~nm}$ phenylacetic acid as well as benzoic acid exhibits appreciable absorption and at $21 \mathrm{I} \mathrm{nm}$ benzoic, phenylacetic and 3-phenylpropionic acids all absorb strongly. The molecular extinctions (the molecular weight of benzoic acid was used for all three acids so that results of calculations were expressed in terms of $\mathrm{BAE}$ ) at these wavelengths are recorded in Table $I$ and these values were used in the calculation of the amounts of each acid present.

Cinnamic acid, if present, would be extracted by light petroleum. This acid exhibits a very strong absorption at $272 \mathrm{~nm}\left(E_{\max }=20500\right)$ and its presence was not detected in these experiments. 
Hippuric acid in diethyl ether extracts of unhydrolysed urine. 'The extracts were made as already described and the solvent was removed. The residue was taken up in $10 \mathrm{ml}$ methanol, and portions containing up to $80 \mu \mathrm{g}$ hippuric acid were applied to $20 \times 20$ $\mathrm{cm}$ thin-layer plates spread with a $250 \mu \mathrm{m}$ layer of silica gel (MN-Kieselgel G; Machery, Nagel \& Co.). The plates were activated for $\mathrm{I} h$ at $120^{\circ}$ before use. Three spots of urine extract and three spots of a freshly prepared standard solution of hippuric acid in methanol were applied to each thin-layer plate.

The developing solvent was: diethyl ether (saturated with water):methanol: formic acid $(87 \%, \mathrm{w} / \mathrm{v}), 98: \mathrm{r}: \mathrm{r}(\mathrm{v} / \mathrm{v})$ (Min \& Schreiber, r 966$)$. The chromatography tanks were lined with filter paper and the plates were developed in an atmosphere saturated with solvent vapour. The solvent front moved about $12 \mathrm{~cm}$ in $30 \mathrm{~min}$ and was removed by heating the plate in an oven at $100^{\circ}$. After it had cooled the plate was sprayed with the reagent of Gaffney, Schreier, DiFerrante \& Altman (1954) which contains $p$-dimethylaminobenzaldehyde in acetic anhydride. The plates were heated in an oven at $145^{\circ}$ for $3 \mathrm{~min}$ and the hippuric acid was converted into its orangecoloured azlactone which has a maximum extinction at $475 \mathrm{~nm}$. The azlactone was eluted from the silica gel with chloroform:methanol $(\mathrm{I}: \mathrm{I}, \mathrm{v} / \mathrm{v})$ and the optical density of the extract was determined at $475 \mathrm{~nm}$. The reaction of the reagent of Gaffney $e t$ al. (1954) with hippuric acid was incomplete on the thin-layer plates; the molecular extinction of the hippuric acid azlactone prepared as described by Gaffney et al. (1954) was $5.60 \times 10^{4}$, whereas that of eluates of hippuric acid azlactone from plates spotted with known amounts of hippuric acid was found to vary between $0.60 \times 10^{4}$ and $\mathrm{r} .80 \times 10^{4}$. However, within any one plate the coefficient of variation of the molecular extinction of hippuric acid spots was found to vary between 5.3 and $13.6 \%$. The average molecular extinction of the standard hippuric acid eluates was used as the factor to calculate the amounts of hippuric acid present in the unknown samples on that plate. Recoveries of hippuric acid added to samples of urine varied between 92.3 and $103 \%$. In addition to hippuric acid, the urine samples might also have contained phenylacetylglycine and phenolic acid-glycine conjugates. Hippuric acid and phenylacetylglycine are not completely separated by the system of thin-layer chromatography used. In this system the $R_{f}$ values of hippuric acid, phenylacetylglycine and $o$-hydroxyhippuric acid were $0.53,0.49$ and 0.81 respectively. With the reagent of Gaffney et al. (1954) phenylacetylglycine gave a yellow-coloured azlactone with maximum absorption at $375 \mathrm{~nm}$. The molecular extinction of the azlactone of phenylacetylglycine at $475 \mathrm{~nm}$ was $4 \%$ of that of hippuric acid. Thus any overestimation of the hippuric acid due to the incomplete resolution of hippuric acid and phenylacetylglycine by thinlayer chromatography was probably very small.

Urinary creatinine. A portion $(0 \cdot 1 \%$ of the total volume excreted in $24 \mathrm{~h}$ ) was diluted to $20 \mathrm{ml}$ and $\mathrm{I} \mathrm{ml}$ was passed through a column of DEAE A-50 Sephadex (Pharmacia Ltd, Uppsala, Sweden) as described by McEvoy-Bowe (I966). Ultraviolet-absorbing anions such as hippurate are retained on the column, and creatinine, which has an absorption maximum at $235 \mathrm{~nm}$, passes through. Care was taken that the ionic strength of the sample applied was not great enough to cause hippurate to be eluted from the column. 


\section{Statistical analyses}

Analyses of variance were made to assess the significance of trends in the various urine fractions examined during starvation. The urine sample from sheep no. 3 on the final day of starvation was lost. The results for this day have been calculated as described for missing values by Snedecor (1940). One result was lost after analysis: it was that for sheep no. $\mathbf{I}$, on day 2, for the diethyl ether-soluble acids of hydrolysed urine. An estimate of this result was calculated by iteration as described by Snedecor (I940).

\section{RESULTS}

The mean urinary excretions by all the sheep of creatinine and the various urine acid fractions investigated, plotted in graphical form, are given in Fig. 2. There was a rapid fall in the totals for each acid fraction during the first 2 days of starvation (days 2 and 3 ) with smaller changes during the $3^{\text {rd }}$ and 4 th days of starvation (days 4 and 5 ). Where analysis of variance showed significant differences due to duration of

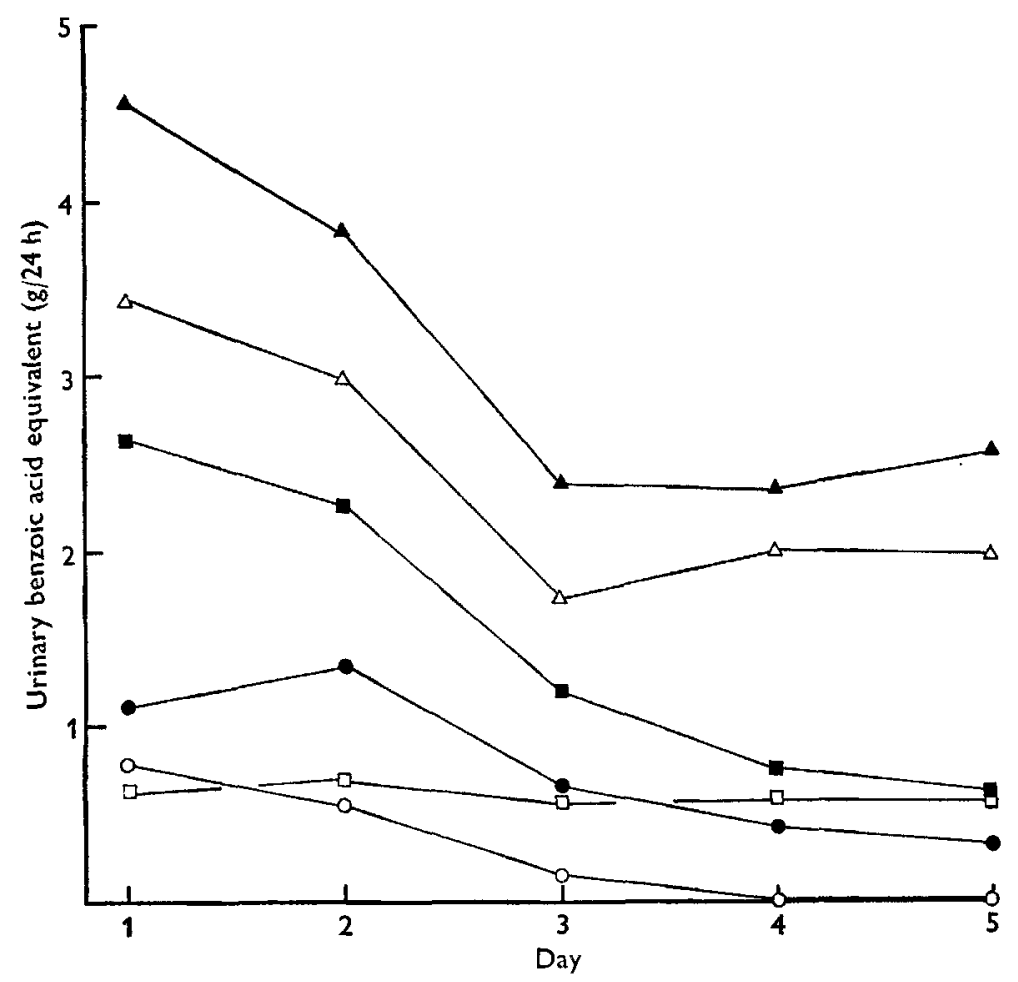

Fig. 2. Average urinary excretion of diethyl ether-soluble acids, total aromatic acids, total conjugated aromatic acids, hippuric acid (as $g$ benzoic acid equivalent $/ 24 h$ ) and creatinine $(\mathrm{g} / \mathbf{2 4} \mathrm{h}$ ) by sheep offered hay (day $\mathrm{I}$ ) and subsequently starved for 4 days (days $2-5) . \Delta-\Delta$, diethyl ether-soluble acids of hydrolysed urine; $\triangle-\triangle$, diethyl ether-soluble acids of unhydrolysed urine; $\mathbf{n}-\mathbf{m}$, total aromatic acid excretion (light petroleum-soluble acids of hydrolysed urine); - conjugated aromatic acid excretion (difference between the light petroleumsoluble acids of hydrolysed and unhydrolysed urine); $\bigcirc-O$, hippuric acid; $\square-\square$, creatinine. 
experiments or between sheep these were further investigated by the $t$ test. Standard errors of day means (based on residual mean square) for hydrolysed urine were (in g BAE $/ 24 \mathrm{~h}$ ): diethyl ether-soluble acids, $\pm 0 \cdot 20 \mathrm{~g}$; light petroleum-soluble acids, $\pm 0 . \mathrm{I} \mathrm{g}$. Values for unhydrolysed urine were: diethyl ether-soluble acids, $\pm 0.20 \mathrm{~g}$; hippuric acid, $\pm 0.13 \mathrm{~g}$; conjugated aromatic acids, $\pm 0.22 \mathrm{~g}$; and creatinine $\pm 0.06 \mathrm{~g} / 24 \mathrm{~h}$.

\section{Diethyl ether-soluble acids}

Hydrolysis of urine resulted in an increase--usually between 20 and $30 \%$-in the acids extracted by diethyl ether. There was a significant difference between sheep $(0.001<P<0.01)$ in the amounts of diethyl ether-soluble acids in hydrolysed urine. Sheep no. 3 excreted significantly smaller quantities than the other sheep. The fall in these acids in hydrolysed urine with time was significant $(P<0.00 \mathrm{I})$, significant reductions being found between days $I$ and 2 (O.0I $<P<0.05)$ (average figures were 4.56 and $3.82 \mathrm{~g} \mathrm{BAE}$ respectively) and between days 2 and $3(P<0.00 \mathrm{I})$ (mean values were 3.82 and $2.39 \mathrm{~g}$ BAE respectively). Continued starvation did not significantly change the excretion of acids in this fraction from the amounts found on day 3 . The excretion of diethyl ether-soluble acids of unhydrolysed urine showed similar trends to those for hydrolysed urine with the exception that analysis of variance showed no between-sheep differences. The average urinary BAE output fell from $3.43 \mathrm{~g} \mathrm{BAE}$ on day $x$ to $\mathrm{I} \cdot 73 \mathrm{~g} \mathrm{BAE}$ on day 3 . On the $4^{\text {th }}$ day of starvation the average amounts of urinary $\mathrm{BAE}$ found in diethyl ether extracts of hydrolysed and unhydrolysed urine were 57 and $58 \%$ respectively of those found when sheep were offered hay.

\section{Acids soluble in light petroleum}

As found with the diethyl ether-soluble acids, a significant difference was observed between sheep in the acids extracted from hydrolysed urine. This was again due to a significantly smaller output of acids by sheep no. 3 . The fall in excretion of acids with time was again significant $(P<0.00 \mathrm{I})$, significant falls being observed between days $\mathrm{I}$ and $2(0.01<P<0.05)$ (average urinary BAE 2.64 and $2.27 \mathrm{~g} / 24 \mathrm{~h}$ respectively), days 2 and $3(P<0.001)$ (average BAE $2 \cdot 27$ and $\mathrm{I} \cdot 2 \mathrm{I} \mathrm{g} / 24 \mathrm{~h}$ respectively) and days 3 and 4 (0.0I $<P<0.05$ ) (average BAE I.2I and $0.77 \mathrm{~g} / 24 \mathrm{~h}$ respectively).

\section{Conjugated aromatic acids}

The difference between the acidity of light petroleum extracts of hydrolysed and unhydrolysed urine represents that due to conjugated aromatic acids (i.e. conjugates of benzoic acid, phenylacetic acid and 3-phenylpropionic acid with glycine or glucuronic acid) in the urine samples analysed. These figures have been included in Fig. 2 to enable an estimate to be made of the proportion of the conjugated aromatic acids which were present as hippurate. Significant falls were found in the excretion of conjugated aromatic acids between days 2 and $3(0.01<P<0.05)$ (average BAE $\mathrm{I} \cdot 36$ and $0.67 \mathrm{~g} / 24 \mathrm{~h}$ respectively) and days 2 and 5 (0.00I $<P<0.0 \mathrm{I}$ ) (average BAE $\mathrm{I} \cdot 36$ and $0.33 \mathrm{~g} / 24 \mathrm{~h}$ respectively). There was no significant fall in conjugated acid output during the final 3 days of starvation. There were no significant differences between sheep. 


\section{Hippuric acid}

This was almost undetectable in the urine samples analysed on the final 3 days of starvation. The fall in hippuric acid output between days $I$ and 3 was significant $(P<0.00 \mathrm{I})$ (average BAE 0.79 and $0.15 \mathrm{~g} / 24 \mathrm{~h}$ respectively). There were no significant differences between sheep.

\section{Creatinine}

There were no significant differences between sheep, and starvation had no influence on the amounts excreted, the average being $0.62 \mathrm{~g}$ creatinine $/ 24 \mathrm{~h}$.

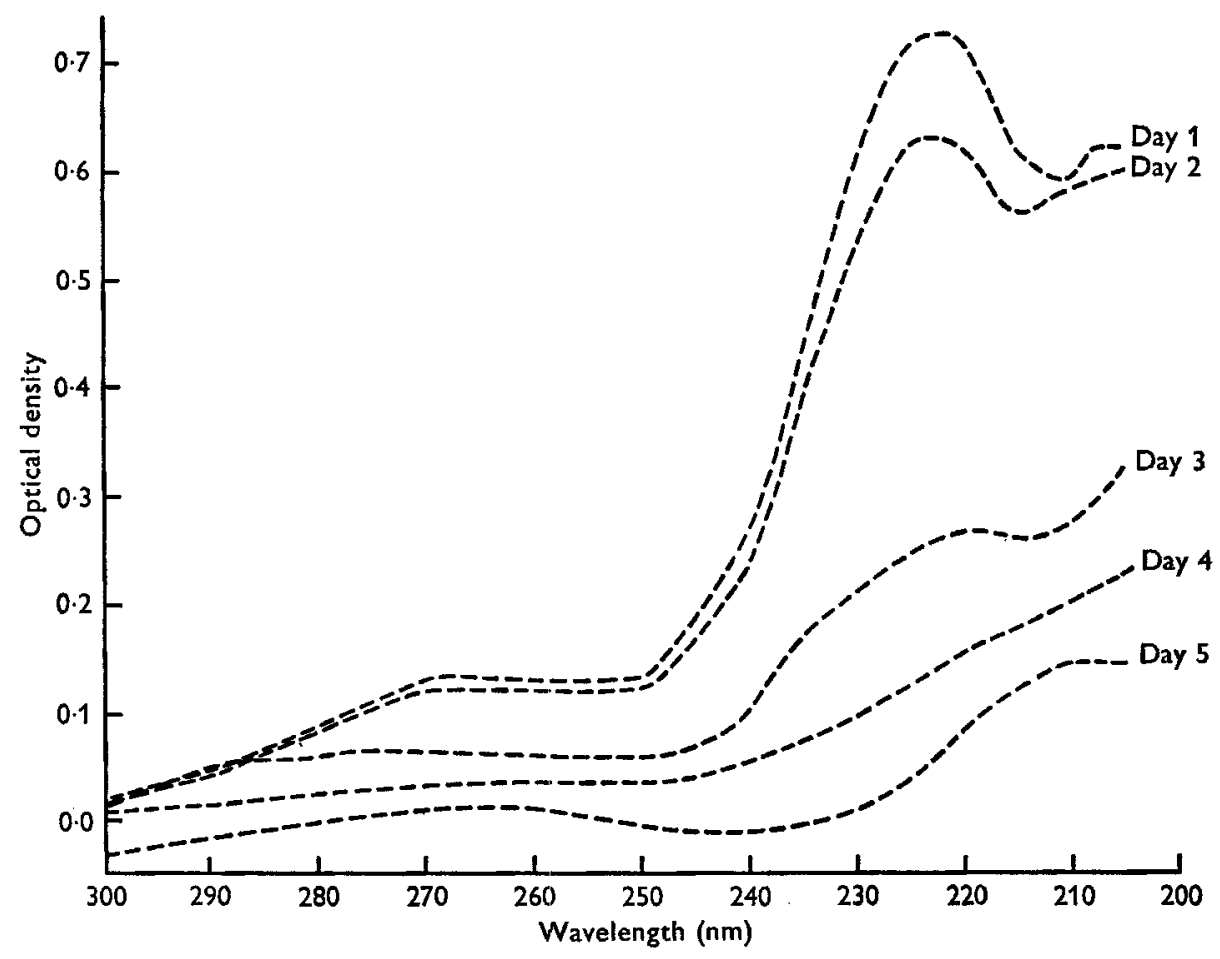

Fig. 3. Absorption curves of aromatic acids extracted from light petroleum (boiling range $40-60^{\circ}$ ) extracts of hydrolysed urine when sheep no. 4 was given hay (day I) and then starved for 4 consecutive days (days $2-5$ ).

\section{Benzoic acid and phenylacetic acids}

The similarity of the absorption curves of phenylacetic and 3-phenylpropionic acids makes the error attached to their estimation large. Other experiments in this laboratory (A. K. Martin, unpublished observations) in which gas-liquid chromatographic analyses of the urinary aromatic acids excreted by sheep have been made have indicated that benzoic and phenylacetic are the major urinary aromatic acids excreted. Only traces of 3 -phenylpropionic and no other aromatic acids were found. The sum of the BAE excreted as phenylacetic acid and 3-phenylpropionic acid calculated by the ultraviolet spectrophotometric technique described in this paper is, therefore, reported 
as phenylacetic acid. The absorption curves obtained in one of the experiments in which the aromatic acids present in the light petroleum extract of hydrolysed urine were partitioned are illustrated in Fig. 3. The absorption maximum at $225 \mathrm{~nm}$ disappeared as the benzoic acid content of the sample fell during starvation.

Table 2. Partition of the aromatic acids found in light petroleum $\left(40-60^{\circ}\right)$ extracts of hydrolysed urine when sheep were offered hay (day I) and then starved for 4 consecutive days (days 2-5). Values for the hippuric acid found in diethyl ether extracts of unhydrolysed urine are also given

(The results are the mean of those with sheep nos. 2 and 4 and are given in $g$ benzoic acid equivalent $/ 24 \mathrm{~h}$. The range is given in parentheses)

\begin{tabular}{|c|c|c|c|c|c|}
\hline Day & $\begin{array}{l}\text { Total light } \\
\text { petroleum- } \\
\text { soluble acids }\end{array}$ & Benzoic acid & $\begin{array}{c}\text { Phenylacetic } \\
\text { acid }\end{array}$ & $\begin{array}{c}\text { Sum of } \\
\text { benzoic and } \\
\text { phenylacetic } \\
\text { acids }\end{array}$ & Hippuric acid \\
\hline I & $\begin{array}{c}2 \cdot 59 \\
(2 \cdot 56-2 \cdot 62)\end{array}$ & $\begin{array}{c}2 \cdot 20 \\
(2 \cdot 13-2 \cdot 27)\end{array}$ & $\begin{array}{c}0.43 \\
\left(0 \cdot 3^{8-0.47)}\right)\end{array}$ & $\begin{array}{c}2 \cdot 63 \\
(2 \cdot 60-2 \cdot 65)\end{array}$ & $\begin{array}{c}0.72 \\
\left(0.55^{-0.79)}\right.\end{array}$ \\
\hline 2 & $\begin{array}{c}2 \cdot 44 \\
(2 \cdot 32-2 \cdot 54)\end{array}$ & $\begin{array}{c}2 \cdot 08 \\
(2 \cdot 07-2 \cdot 08)\end{array}$ & $\begin{array}{c}0.45 \\
(0.37-0.53)\end{array}$ & $\begin{array}{c}2 \cdot 53 \\
(2 \cdot 45-2 \cdot 65)\end{array}$ & $\begin{array}{c}0.40 \\
(0.20-0.61)\end{array}$ \\
\hline 3 & $\begin{array}{c}1 \cdot 35 \\
\left(1 \cdot 33^{-1} \cdot 36\right)\end{array}$ & $\begin{array}{c}0.96 \\
(0.92-1 \cdot 00)\end{array}$ & $\begin{array}{c}0.43 \\
(0.43,0.43)\end{array}$ & $\begin{array}{c}I \cdot 39 \\
(I \cdot 35-I \cdot 43)\end{array}$ & $\begin{array}{c}0.09 \\
\left(0.05^{-0.13)}\right.\end{array}$ \\
\hline 4 & $\begin{array}{c}0.79 \\
(0.67-0.92)\end{array}$ & $\begin{array}{c}0.34 \\
(0.29-0.39)\end{array}$ & $\begin{array}{c}0.39 \\
\left(0.37^{-0.41}\right)\end{array}$ & $\begin{array}{c}0.73 \\
(0.66-0.80)\end{array}$ & $\begin{array}{c}0.02 \\
(0.01-0.02)\end{array}$ \\
\hline 5 & $\begin{array}{c}0.78 \\
(0.64-0.93)\end{array}$ & $\begin{array}{c}0.19 \\
(0.14-0.23)\end{array}$ & $\begin{array}{c}0.43 \\
(0.36-0.50)\end{array}$ & $\begin{array}{c}0.62 \\
0.50-0.73)\end{array}$ & $\begin{array}{c}0.01 \\
(0.01,0.01)\end{array}$ \\
\hline
\end{tabular}

In Table 2 the average total amounts of acids soluble in light petroleum extracted from hydrolysed urine of sheep 2 and 4 are recorded together with the contents of benzoic and phenylacetic acids determined by ultraviolet absorption spectrophotometry. The sum of the benzoic and phenylacetic acids corresponds closely to the total titratable acids found during days $\mathrm{I}-4$. The sum of these acids was about $20 \%$ less than the titratable acidity found on day 5 in both experiments. The benzoic acid excreted in the urine of sheep fell rapidly on withholding food. On day I, 2.20 g BAE/ $24 \mathrm{~h}$ were excreted and on day 5 , only $0.19 \mathrm{~g} / 24 \mathrm{~h}$. In contrast, the phenylacetic acid excretion remained unaffected by starvation; it did not vary significantly from the mean vlaue of $0.43 \mathrm{~g} \mathrm{BAE} / 24 \mathrm{~h}$ found when hay was offered. The average hippuric acid excretion ( $\mathrm{g} \mathrm{BAE} / 24 \mathrm{~h}$ ) of these sheep is given for comparison with the total benzoic acid output.

\section{DISCUSSION}

To reduce the period of starvation required to reach endogenous levels of urinary organic acid excretion the sheep used in these experiments were given a poor-quality hay before starvation. Studies in this laboratory and elsewhere summarized by Martin (1969) have shown mature roughages to contain comparatively small amounts of aromatic acid precursors. With all the urine fractions examined there were no significant differences between the quantities excreted on the $3^{\text {rd }}$ and $4^{\text {th }}$ days of starvation.

Only aromatic acids in the diethyl ether-soluble acid fraction have been studied in 
detail. The rise in diethyl ether-soluble acids which occurs on hydrolysis of urine may perhaps in part be due to the hydrolysis of glucuronides or sulphates of aromatic or phenolic acids which are not soluble in diethyl ether; estimates of glucuronide output were not made.

When sheep were offered hay (day I) the average urinary excretion of diethyl ethersoluble acids of hydrolysed urine as BAE was $4.56 \mathrm{~g} / 24 \mathrm{~h}$ compared with $2.5^{8} \mathrm{~g} / 24 \mathrm{~h}$ at the end of the 4-day period of starvation (see Fig. 2). Of these acids, on day i $58 \%$ $(2.64 \mathrm{~g} \mathrm{BAE})$ was excreted in the form of aromatic acids, i.e. benzoic acid and its homologues, compared with only $24 \%(0.63 \mathrm{~g})$ on day 5 . If it be assumed that dietary sources of aromatic acids were no longer available by the $4^{\text {th }}$ day of starvation, it may be concluded that $76 \%$ of the total aromatic acid output of the sheep (2.01 $\mathrm{g}$ $\mathrm{BAE}$ ) originated from precursors in the hay.

The endogenous excretion of small amounts of benzoic acid is well documented (e.g. Schreier et al. 1954). This has been shown to be independent of the bacterial flora of the intestine in laboratory animals. The metabolic pathways involved are not clear. Bruns, Haberland \& Altman (1959) have demonstrated that phenylalanine and, to a greater extent, $\mathrm{L}$-threo- $\beta$-phenylserine, may act as precursors of urinary benzoic acid. Enzymes are present in sheep liver tissue which will metabolize phenylserine to benzaldehyde and glycine. The activity of this enzyme falls during starvation (Bruns \& Fiedler, 1958). It is not known whether phenylserine is an intermediate in the endogenous production of benzoic acid, and this amino acid has not yet been demonstrated to occur in nature (Meister, 1965 ). Endogenously produced phenylacetic acid probably arises by decarboxylation of phenylpyruvic acid derived from phenylalanine (Moldave \& Meister, 1957; Asakawa, Wada \& Yamano, 1968).

Reports on the quantitative endogenous output of aromatic acids are few. Stein et al. (1954) have reported values for hippuric acid and phenylacetylglutamine excretion by man when given normal diets and reported no difference when the subjects were fasted. They did not state the period of fast. Their results have been expressed in terms of $\mathrm{mg} \mathrm{BAE} / \mathrm{kgW}^{0.75}$ per $24 \mathrm{~h}$ (assuming a body-weight of $70 \mathrm{~kg}$ for an adult man); between 28 and $70 \mathrm{mg} \mathrm{BAE} / \mathrm{kgW}^{0.75}$ per $24 \mathrm{~h}$ were excreted as hippurate and between 5 and $10 \mathrm{mg}$ as phenylacetylglutamine. Armstrong et al. (1955), who investigated the endogenous output of hippuric acid by man and the rat, found that I or 2 days were required before basal levels of excretion were achieved and found very much lower quantities than reported by Stein et al. (1954): Armstrong et al. found that man excreted $\mathrm{I} \cdot 4-3.9 \mathrm{mg} \mathrm{BAE} / \mathrm{kgW}^{0.75}$ per $24 \mathrm{~h}$ and rats $6 \cdot 4 \mathrm{mg}$. An inadequate period of fast may explain the high results reported by Stein $e t$ al. (1954). In the present experiments the total output of aromatic acids (i.e. benzoic and phenylacetic acids) by sheep varied between $28 \cdot \mathrm{I}$ and $42 \cdot 3 \mathrm{mg} \mathrm{BAE} / \mathrm{kgW}{ }^{0.75}$ per $24 \mathrm{~h}$ on the $4^{\text {th }}$ day of starvation.

Partition of the aromatic acids excreted showed that while benzoic acid comprised between 80 and $90 \%$ of the total aromatic acids when sheep were fed, it made up only $22-25 \%$ of these acids at the end of the starvation period. The endogenous benzoic acid outputs of the sheep on the 4 th day of starvation were $6 \cdot 1$ (sheep no. 2) and 10.5 (sheep no. 4) mg BAE $/ \mathrm{kgW}^{0.75}$ per $24 \mathrm{~h}$. These results are of a similar order to those 
reported for rats by Armstrong et al. (1955). While benzoic acid excretion fell rapidly with increasing duration of fast, phenylacetic acid output remained the same as when the sheep were offered hay. The excretions of phenylacetic acid by the two sheep on the final day of starvation were $15^{\circ} 9$ and $22.7 \mathrm{mg} \mathrm{BAE} / \mathrm{kgW}^{0.75}$ per $24 \mathrm{~h}$, which are greater than the values reported by Stein $e$ al. (1954) for man. Rumen fermentation during the 4 th day of fast may be responsible for a proportion of the aromatic acids excreted. Phenylalanine undergoes fermentation in the rumen to yield phenylacetic acid, and tyrosine, to a lesser extent, is metabolized to yield 3-phenylpropionic acid (Scott, Ward \& Dawson, 1964; Patton \& Kesler, 1967). Blaxter (1962) has reported that sheep fasted for 4 days produce small amounts of methane (between 4 and $8 \%$ of the amounts when fed) and that there were significant differences between sheep in their methane production when fasted. Variation between sheep in the extent of continuing rumen fermentation during fasting may explain the significantly lower output of acids by sheep no. 3 compared with the other sheep in the diethyl ethersoluble and light petroleum-soluble fractions of hydrolysed urine.

In these experiments the proportion of the total benzoic acid excreted in urine conjugated as hippurate fell with increasing duration of fast (Table 2). Hippuric acid is unstable in ruminant urine so the results for hippuric acid in Table 2 may be underestimates of the amounts excreted. Analyses were not made of the free benzoic acid content of the samples as analysed so the proportion of benzoic acid in the conjugated acid fraction (Fig. 2) of the samples as analysed cannot be calculated. The greater rate of fall in hippurate excretion compared with the total benzoic acid output on starvation would suggest that the proportion of benzoic acid conjugated as hippurate falls when sheep are starved. Thus, on days I, 2, 3, 4 and 5, the percentages of the total benzoic acid excreted in the urine found to be conjugated with hippurate were 33, 19, 9, 6 and $5 \%$ respectively (Table 2 ). Bray, Thorpe \& White (r95I) were able to predict the proportion of benzoic acid conjugated with glycine or glucuronic acid from the availability of glycine in the body. It might be expected that, during starvation, glycine availability would fall and, hence, hippurate output might also fall. Determination of endogenous benzoic acid output by estimation of urinary hippurate in fasted animals may then underestimate the total output.

In further experiments it is hoped to investigate the effects of longer periods of starvation to find whether all exogenous sources of benzoic and phenylacetic acids (from continuing rumen fermentation) were removed in these experiments. Study will also be made of the mode of conjugation of the acids excreted during starvation and the quantity and identity of phenolic acids excreted. The present experiments have demonstrated that the greater part of the benzoic acid excreted by sheep is derived from precursors in their diet.

The author is indebted to his colleagues in the Institute for helpful discussions and, in particular, to $\mathrm{Dr}$ J. H. Moore for his advice and encouragement. The experimental animals were in the care of Mr J. McDill, and Miss J. T. Begg and Miss G. Falconer rendered skilled analytical assistance. 


\section{REFERENCES}

Armstrong, M. D., Chao, F.-C., Parker, V. J. \& Wall, P. E. (1955). Proc. Soc, exp. Biol. Med. 9o, 675. Asakawa, T., Wada, H. \& Yamano, T. (1968). Biochim. biophys. Acta r7o, 375.

Bernard, K., Vuilleumier, J. P. \& Brubacher, G. (1955). Helv. chim. Acta 38, 4438.

Blaxter, K. L. (1962). Br. Ұ. Nutr. r6, 6 I 5 .

Bray, H. G., Thorpe, W. V. \& White, K. (1951). Biochem. F. 48, 88.

Bruns, F. H. \& Fiedler, L. (1958). Nature, Lond. I81, I 533.

Bruns, F. H., Haberland, G. L. \& Altman, K. I. (1959). Biochem. Z. 33I, 446.

Gaffney, G. W., Schreier, K., Diferrante, N. \& Altman, K. I. (1954). F. biol. Chem. $206,695$.

Kumler, W. D. \& Strait, L. A. (1943). F. Am. chem. Soc. 65, 2349.

McEvoy-Bowe, E. (1966). Analyt. Biochem. I6, I 53.

Martin, A. K. (1966). Br. F. Nutr. 20, 325.

Martin, A. K. (1969). Br. Y. Nutr. 23, 289.

Meister, A. (1965). Biochemistry of the Amino Acids, and ed., p. 152. London: Academic Press Inc.

Min, B. H. \& Schreiber, E. C. (I 966). F. Chromat. 24, 463.

Moldave, K. \& Meister, A. (1957). Biochem. biophys. Acta 24, 654.

Patton, S. \& Kesler, E. M (I 967). F. Dairy Sci. 50, 1505.

Schreier, K., Altman, K. I. \& Hempelmann. L. H. (1954). Proc. Soc. exp. Biol. Med. 87, 6r.

Scott, T. W., Ward, P. F. V. \& Dawson, R. M. C. (1964). Biochem. F. 90, 12.

Snedecor, G. W. (1940). Statistical Methods, $3^{\text {rd }}$ ed., p. 223. Ames, Iowa: Iowa College Press.

Stein, W. H., Paladini, A. C., Hirs, C. H. W. \& Moore, S. (r954). F. Am. chem. Soc. 76, 2848. 